\title{
Calcific panniculitis and nasopharyngeal cancer-associated adult-onset dermatomyositis: a case report and literature review
}

\author{
Manasmon Chairatchaneeboon", Kanokvalai Kulthanan and Araya Manapajon
}

\begin{abstract}
Panniculitis is an uncommon cutaneous manifestation in dermatomyositis. It not only occurs in idiopathic dermatomyositis, but also rarely occurs in the setting of malignancy-associated dermatomyositis. Calcinosis cutis is also less likely to be found in adult-onset dermatomyositis. In malignancy-associated dermatomyositis, panniculitis can precede, concur, or follow the diagnosis of malignancy. We report the case of a 26-year-old Thai female with calcific panniculitis in the setting of adult-onset dermatomyositis associated with nasopharyngeal cancer. The clinical course of calcific panniculitis in our case was not parallel to the course of malignancy. Calcific panniculitis can appear many years after, despite the remission of the cancer. A thorough review of the previously reported literature is also provided.
\end{abstract}

Keywords: Adult; Calcinosis; Dermatomyositis; Nasopharyngeal neoplasm; Panniculitis

\section{Introduction}

Panniculitis is an uncommon cutaneous manifestation in dermatomyositis. Since 1924, fewer than 30 cases of panniculitis-associated dermatomyositis have been reported. It not only occurs in idiopathic dermatomyositis, but also rarely occurs in the setting of malignancyassociated dermatomyositis (Girouard et al. 2012). To our knowledge, only 4 cases of panniculitis in the setting of malignancy-associated dermatomyositis have been documented.

\section{Case report}

A 26-year-old Thai female presented with Gottron's papules, heliotropes, and proximal muscle weakness for 3 months. Investigations showed elevation of creatine phosphokinase, lactic dehydrogenase, and positive antinuclear antibodies (ANA) at the titer of 1:320 (fine speckled pattern). However, negative results were found for anti-dsDNA, anti-Sm, anticardiolipin antibodies, and anti $\beta_{2}$ glycoprotein1antibodies. Lupus anticoagulant and complement level (C3, C4) were normal. Myositisspecific and associated antibodies, including anti-Mi2,

\footnotetext{
* Correspondence: mallydoc@hotmail.com

Department of Dermatology, Faculty of Medicine Siriraj Hospital, Mahidol University, 2 Wanglang Road, 10700 Bangkok, Thailand
}

anti-Ku, anti-PM-Scl-100, anti-PM-Scl-75, anti-Jo-1, anti-PL-7, anti-PL-12, anti-Ro-52, anti-SRP, anti-EJ, and anti-OJ, were all negative. Electromyography (EMG) study demonstrated increased duration of small polyphasic motor unit action potential (MUAP) with early motor unit recruitment, which is compatible with myositis. With 4 of 5 Bohan and Peter diagnostic criteria (Bohan and Peter 1975a, b) for dermatomyositis being met, a diagnosis of dermatomyositis was made without performing muscle biopsy. The patient was treated with chloroquine $250 \mathrm{mg} /$ day, azathioprine $100 \mathrm{mg} /$ day, and prednisolone $30 \mathrm{mg} /$ day. One month after diagnosis of dermatomyositis, our patient was found to have a posterior pharyngeal wall mass and was diagnosed as non-keratinizing nasopharyngeal carcinoma stage IV (T3N3bN0). Following a course of concurrent chemoradiation, nasotelescopy was performed and remission of the malignancy was confirmed. Two years after remission, Gottron's papules, heliotropes, and muscle power improved, but she developed an ill-defined indurated plaque on her right arm. There was no history of previous trauma to the area. Magnetic resonance imaging (MRI) then revealed diffuse inflammatory process involving skin along right upper arm to proximal forearm, with underneath subcutaneous fat necrosis and marked skin 
thickening. Five months later, she experienced progressive hardening of skin on her arms, legs, and abdomen. On physical examination, there were multiple, nontender, fixed, hard-to-bony consistency, dermal to subcutaneous nodules and plaques on axillae, arms (Figure 1), legs, and left lower quadrant of abdominal wall. The lesions varied in size from 1.5 to $5 \mathrm{~cm}$ and were mild tender on palpation. Plain radiographs showed softtissue calcification along extremities (Figure 2). A biopsy of subcutaneous nodule on her right upper extremity revealed calcification, degeneration of subcutaneous fat cells, and septal fibrosis underneath basal vacuolar degeneration with melanin incontinence and dermal mucin deposition (Figure 3). Lipomembranous change was observed in subcutaneous fat. Serum calcium and phosphate level were normal. Colchicine $0.6 \mathrm{mg} /$ day was initiated for the treatment of calcinosis, without significant change in the lesions.

\section{Discussion}

Adult patients with dermatomyositis are more likely to develop panniculitis than children. Clinical presentation includes painful subcutaneous nodules, indurations, plaques, and/or lipoatrophy. The presence of panniculitis may precede, concur, or occur up to 5 years after diagnosis of dermatomyositis. Table 1 shows characteristics of documented cases of adult-onset dermatomyositis-associated panniculitis. In our case, the

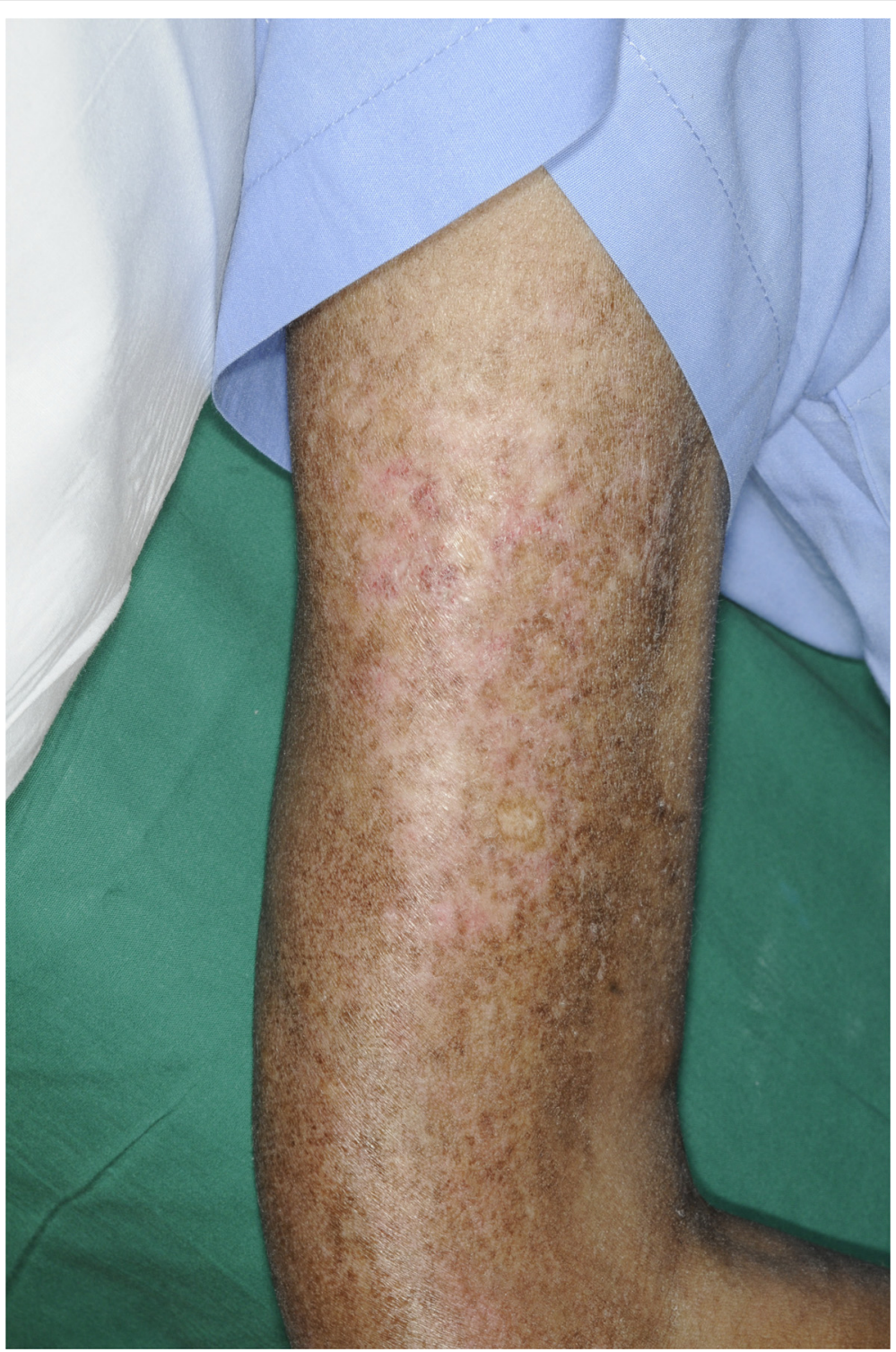

Figure 1 Calcinosis cutis on right arm characterized by multiple, hard to bony consistency, dermal to subcutaneous plaques. 


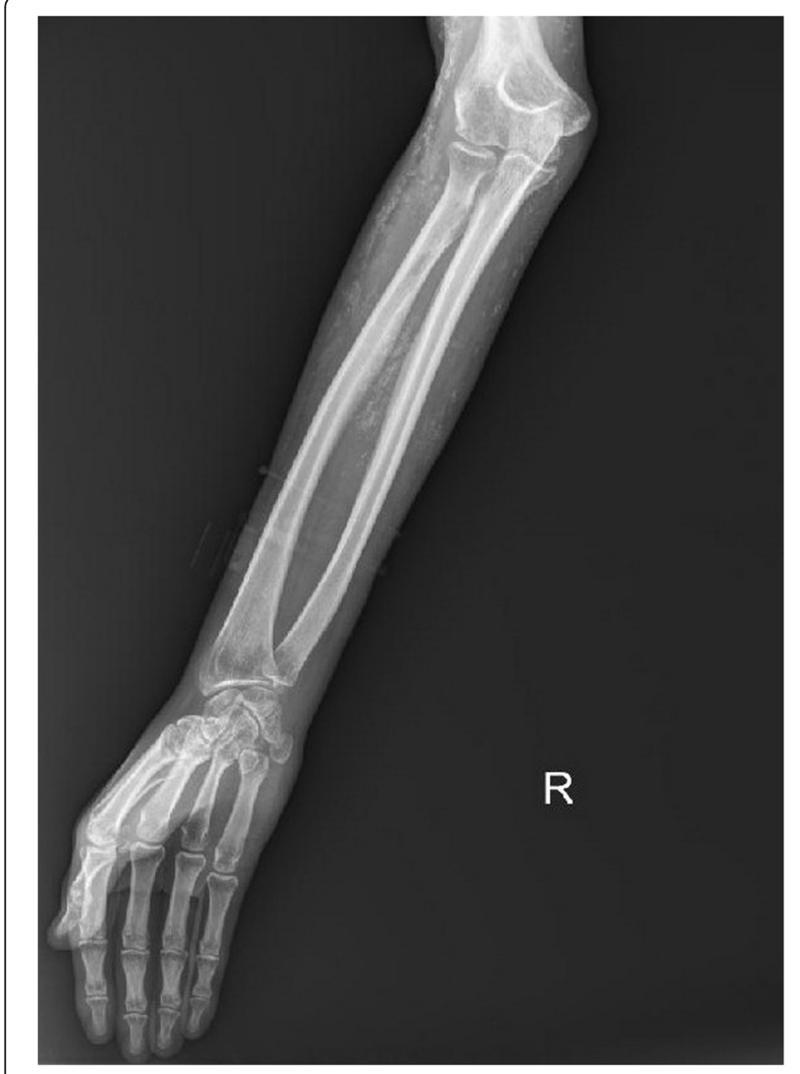

Figure 2 Plain radiographs showing soft-tissue calcification along right arm. patient developed indurated plaques on her arms 2 years after being diagnosed with dermatomyositis.

Although panniculitis is an uncommon presentation in adult-onset dermatomyositis, microscopic changes in adipose tissue were more common than clinically observed (Chao and Yang 2000; Girouard et al. 2012). Panniculitis was found in up to $7 \%$ of skin biopsy specimens from poikilodermatous skin change in dermatomyositis patients (Janis and Winkelmann 1968). Among dermatomyositis cases that had panniculitis, lobular panniculitis with lymphoplasmacytic infiltration, lipomembranous panniculitis, and calcific panniculitis were reported (Girouard et al. 2012; Yamamoto et al. 2007). Consistent with the review by Solans et al. (2002), our case demonstrated degeneration of subcutaneous fat cells, septal fibrosis, and lipomembranous change in subcutaneous tissue underneath basal vacuolar degeneration at the dermoepidermal junction.

In malignancy-associated dermatomyositis, panniculitis can develop from 14 months prior to the diagnosis of malignancy to 4 months after the diagnosis of malignancy (Girouard et al. 2012). Reported associated malignancies include parotid carcinoma, rhabdomyosarcoma, and ovarian adenoma (Girouard et al. 2012). In our case, panniculitis and skin calcinosis occurred 2 years after the diagnosis of nasopharyngeal carcinoma.

In contrast to panniculitis in dermatomyositis, calcinosis cutis is less likely to be found in adult-onset than in juvenile-onset dermatomyositis. Calcinosis cutis presents in up to $20 \%$ of adult-onset cases, as compared to $70 \%$ of juvenile-onset dermatomyositis cases (Gutierrez and Wetter 2012). Extremities and trunk are the common sites

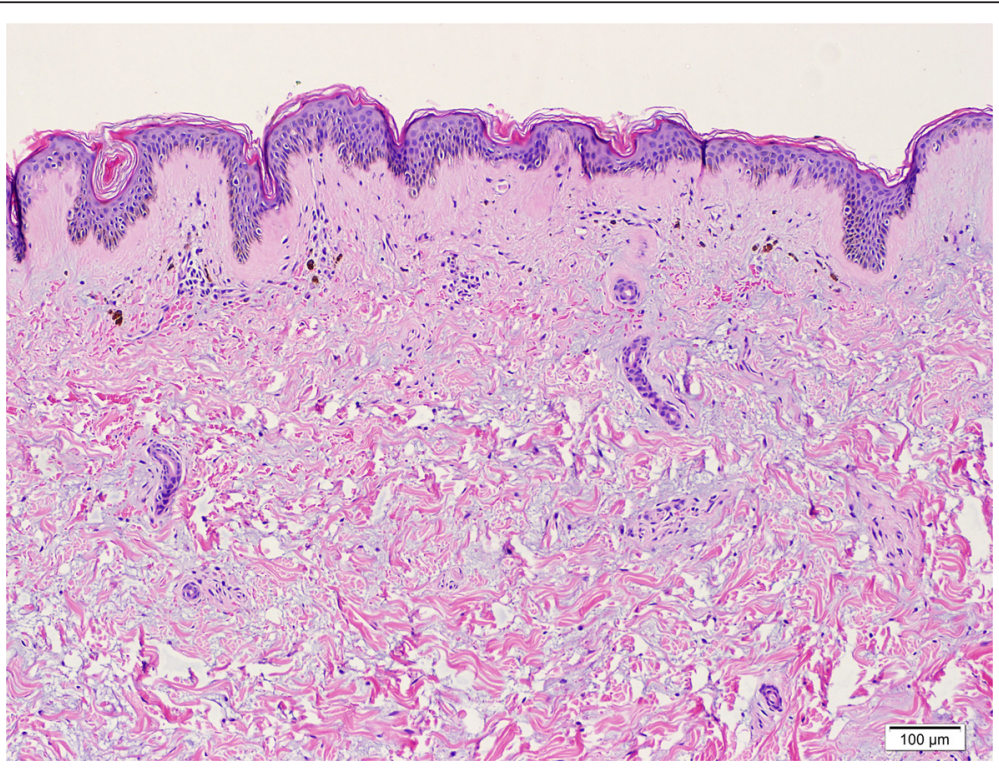

Figure 3 Biopsy showing basal vacuolisation with melanin incontinence and dermal mucin deposition (H\&E, original magnification x10). 
Table 1 Characteristics of documented cases of adult-onset dermatomyositis-associated panniculitis

\begin{tabular}{|c|c|c|c|c|c|c|c|c|}
\hline $\begin{array}{l}\text { Case no./Sex/ } \\
\text { Age, y }\end{array}$ & Reference no. & $\begin{array}{l}\text { Temporal relationship } \\
\text { of panniculitis and } \\
\text { dermatomyositis }\end{array}$ & $\begin{array}{l}\text { Associated } \\
\text { malignancy }\end{array}$ & $\begin{array}{l}\text { Temporal relationship } \\
\text { of panniculitis and } \\
\text { malignancy }\end{array}$ & Number and location & Autoantibodies & Panniculitis features & $\begin{array}{l}\text { Presence of } \\
\text { calcinosis }\end{array}$ \\
\hline $1 / \mathrm{F} / 78 \mathrm{y}$ & (Lorenzo et al. 1998) & 5 months earlier & no & - & N/A & N/A & N/A & N/A \\
\hline $2 / F / 22 y$ & (Weber and Gray 1924) & Concurrent & N/A & - & N/A & N/A & N/A & N/A \\
\hline 3/F/44y & (Chao and Yang 2000) & 2.5 months earlier & NS & - & $\begin{array}{l}\text { Multiple/shoulders, } \\
\text { back, chest, abdomen, } \\
\text { buttock, and bilateral } \\
\text { thighs }\end{array}$ & $\begin{array}{l}\text { ANA 1:80 } \\
\text { (speckled pattern) }\end{array}$ & NS & NS \\
\hline $4 / F / 24 y$ & (Winkelmann et al. 1990) & 4 months earlier & no & - & Single/left arm & Negative & $\begin{array}{l}\text { Lobular panniculitis } \\
\text { with fat necrosis }\end{array}$ & NS \\
\hline $5 / F / 42 y$ & (Fusade et al. 1993) & 10 months earlier & no & - & $\begin{array}{l}\text { Multiple/buttocks, } \\
\text { thighs, arms, abdomen, } \\
\text { breasts }\end{array}$ & Negative & $\begin{array}{l}\text { Lobular panniculitis } \\
\text { with fat necrosis }\end{array}$ & NS \\
\hline 6/F/23y & (Carneiro et al. 2007) & Later & no & - & Multiple/arms & $\begin{array}{l}\text { ANA 1:40 } \\
\text { (speckled pattern) }\end{array}$ & Lobular panniculitis, NS & NS \\
\hline 7/M/19y & (Carrera et al. 2006) & 15 months later & no & - & Several/left thigh & Negative & $\begin{array}{l}\text { Lobular panniculitis } \\
\text { resembling } \\
\text { cytophagichistiocytic } \\
\text { panniculitis }\end{array}$ & NS \\
\hline 8/F/40y & (Feldman et al. 1983) & 1 year later & NS & - & N/A & N/A & Septal panniculitis & NS \\
\hline 9/F/54y & (Molnar et al. 1998) & Concurrent & no & - & Multiple/arms & Negative & Panniculitis, NS & NS \\
\hline 10/F/57y & (Molnar et al. 1998) & Concurrent & no & - & $\begin{array}{l}\text { Multiple/buttocks, } \\
\text { left thigh and sacral }\end{array}$ & $\begin{array}{l}\text { ANA 1:32 } \\
\text { (nucleolar pattern) }\end{array}$ & Lobular panniculitis & NS \\
\hline 11/F/60y & (Nakamori et al. 2003) & 8 months earlier & no & - & Several/arms & ANA 1:640 & Lobular panniculitis & NS \\
\hline 12/F/73y & (Abdul-Wahab et al. 2009) & 4 months later & no & - & $\begin{array}{l}\text { Multiple/anterior } \\
\text { thighs and upper arms }\end{array}$ & NS & NS & yes \\
\hline 13/F/50y & (Abdul-Wahab et al. 2009) & 18 months later & NS & - & $\begin{array}{l}\text { Multiple/extensor of } \\
\text { all extremities }\end{array}$ & $\begin{array}{l}\text { ANA (speckled } \\
\text { pattern) }\end{array}$ & NS & yes \\
\hline 14/F/29y & (Carneiro et al. 2007) & Concurrent & NS & - & Multiple/thighs & $\begin{array}{l}\text { ANA 1:1024 } \\
\text { (speckled pattern) }\end{array}$ & $\begin{array}{l}\text { Lobular panniculitis } \\
\text { with fat necrosis }\end{array}$ & yes \\
\hline 15/M/42y & (Lee et al. 1999) & 1 year earlier & no & - & $\begin{array}{l}\text { Multiple/left buttock } \\
\text { and left inguinal area }\end{array}$ & Negative & $\begin{array}{l}\text { Fat necrosis with } \\
\text { membranocystic change }\end{array}$ & yes \\
\hline 16/F/42y & (Solans et al. 2002) & 17 months later & no & - & $\begin{array}{l}\text { Several/right and left } \\
\text { upper elbow }\end{array}$ & Negative & $\begin{array}{l}\text { Lobular necrotizing } \\
\text { panniculitis }\end{array}$ & yes \\
\hline 17/F/80y & (Solans et al. 2002) & 10 months later & no & - & Single/right inner elbow & $\begin{array}{l}\text { ANA 1:640 } \\
\text { (speckled pattern) }\end{array}$ & Lipomembranous change & yes \\
\hline 18/F/65y & (Ishikawa et al. 1996) & Concurrent & no & - & $\begin{array}{l}\text { Multiple/buttocks, left } \\
\text { thigh, lower right legs }\end{array}$ & Negative & Lipomembranous change & yes \\
\hline 19/F/60y & (Carroll et al. 2014) & 2 year later & NS & - & $\begin{array}{l}\text { Multiple/thighs and } \\
\text { buttocks }\end{array}$ & NS & $\begin{array}{l}\text { Lobular fat necrosis } \\
\text { with PMN infiltration }\end{array}$ & yes \\
\hline
\end{tabular}


Table 1 Characteristics of documented cases of adult-onset dermatomyositis-associated panniculitis (Continued)

\begin{tabular}{|c|c|c|c|c|c|c|c|c|}
\hline 20/F/35y & (Lin et al. 2006) & 8 months earlier & no & - & Multiple/right arm & Negative & Lipomembranous change & no \\
\hline 21/F/56y & (Lin et al. 2006) & 2 year after & Parotid carcinoma & NS & Multiple/arms & $\begin{array}{l}\text { ANA 1:640 } \\
\text { (speckled pattern) }\end{array}$ & Lipomembranous change & no \\
\hline 22/M/51y & (Kuriya et al. 1985) & 14 months earlier & Rhabdomyosarcoma & N/A & Single/buttock & Negative & $\begin{array}{l}\text { Panniculitis with fat } \\
\text { necrosis }\end{array}$ & $\mathrm{N} / \mathrm{A}$ \\
\hline 23/F/52y & (Leung et al. 2005) & Concurrent & Rectum carcinoma & NS & Multiple/thighs & NS & Lobular panniculitis, NS & NS \\
\hline 24/F/63y & (Girouard et al. 2012) & 25 months earlier & Ovarian cancer & $\begin{array}{l}\text { Panniculitis developed } \\
18 \text { years after diagnosis } \\
\text { of malignancy }\end{array}$ & Multiple/arms and thighs & $\begin{array}{l}\text { ANA 1:160 } \\
\text { (speckled pattern) }\end{array}$ & Lobular panniculitis, NS & NS \\
\hline 25/F/26y & Case report & 26 months later & $\begin{array}{l}\text { Nasopharyngeal } \\
\text { cancer }\end{array}$ & $\begin{array}{l}\text { Panniculitis developed } \\
25 \text { months after } \\
\text { diagnosis of malignancy }\end{array}$ & $\begin{array}{l}\text { Multiple/extensor of all } \\
\text { extremities, abdomen }\end{array}$ & $\begin{array}{l}\text { ANA 1:320 } \\
\text { (speckled pattern) }\end{array}$ & Lipomembranous change & yes \\
\hline
\end{tabular}

NS, not specified in report; N/A, data is not available.

ANA, antinuclear antibodies. 
of involvement (Gutierrez and Wetter 2012). Panniculitis is considered the preceding manifestation of the calcific process in dermatomyositis. In our case and consistent with this tendency, there was history of diffuse inflammatory process involving skin along the right arm, with MRI confirming soft tissue inflammation and subcutaneous necrosis prior to the development of calcification. This is consistent with dystrophic calcification. Severity of dystrophic calcification in dermatomyositis ranges from localized small subcutaneous nodules, tumoral deposits, and intramuscular and fascial calcification to severe forms of exoskeleton formation (Gutierrez and Wetter 2012; Reiter Reiter et al. 2011).

\section{Conclusion}

In conclusion, we report the first documented case of calcific panniculitis with lipomembranous change in the setting of adult-onset dermatomyositis associated with nasopharyngeal cancer. The clinical course of our case was not parallel to the course of malignancy. Calcific panniculitis can appear many years after, despite the remission of cancer. However, the association between calcific panniculitis and malignancy-associated dermatomyositis cannot be ascertain by a single case report. Further study and larger case series are needed.

\section{Consent}

Informed consent was obtained from the patient for the publication of this report and any accompanying images.

\section{Competing interests}

The authors declare that they have no competing interests.

\section{Authors' contributions}

MC performed literature review, photographed the slides and revised the manuscript. KK supervised the study and revised the manuscript. AM carried out literature review, reviewed the cases, data collection, and drafted the manuscript. All authors read and approved the final manuscript.

\section{Acknowledgements}

The authors wish to thank Dr. Pranee Kasemsarn for her support in patient care.

Received: 20 April 2015 Accepted: 22 April 2015

Published online: 30 April 2015

\section{References}

Abdul-Wahab A, Holden CA, Harland C, Patel S (2009) Calcific panniculitis in adult-onset dermatomyositis. Clin Exp Dermatol 34(8):e854-e856, doi:10.1111/j.1365-2230.2009.03603.x

Bohan A, Peter JB (1975a) Polymyositis and dermatomyositis (first of two parts). N Engl J Med 292(7):344-347, doi:10.1056/NEJM197502132920706

Bohan A, Peter JB (1975b) Polymyositis and dermatomyositis (second of two parts). N Engl J Med 292(8):403-407, doi:10.1056/NEJM197502202920807

Carneiro S, Alvim G, Resende P, Auxiliadora Jeunon Sousa M, Cuzzi T, Ramos-e-Silva M (2007) Dermatomyositis with panniculitis. Skinmed 6(1):46-47

Carrera E, Lobrinus JA, Spertini O, Gherardi RK, Kuntzer T (2006) Dermatomyositis, lobar panniculitis and inflammatory myopathy with abundant macrophages. Neuromuscul Disord 16(7):468-471, doi:10.1016/j.nmd.2006.05.008

Carroll M, Mellick N, Wagner G (2014) Dermatomyositis panniculitis: A case report. Australas J Dermatol. doi:10.1111/ajd.12172
Chao YY, Yang LJ (2000) Dermatomyositis presenting as panniculitis. Int J Dermatol 39(2):141-144

Feldman D, Hochberg MC, Zizic TM, Stevens MB (1983) Cutaneous vasculitis in adult polymyositis/dermatomyositis. J Rheumatol 10(1):85-89

Fusade T, Belanyi P, Joly P, Thomine E, Mihout MF, Lauret P (1993) Subcutaneous changes in dermatomyositis. Br J Dermatol 128(4):451-453

Girouard SD, Velez NF, Penson RT, Massarotti EM, Vleugels RA (2012) Panniculitis associated with dermatomyositis and recurrent ovarian cancer. Arch Dermatol 148(6):740-744, doi:10.1001/archdermatol.2012.288

Gutierrez A Jr, Wetter DA (2012) Calcinosis cutis in autoimmune connective tissue diseases. Dermatol Ther 25(2):195-206, doi:10.1111/j.1529-8019.2012.01492.x

Ishikawa O, Tamura A, Ryuzaki K, Kurosawa M, Miyachi Y (1996) Membranocystic changes in the panniculitis of dermatomyositis. Br J Dermatol 134(4):773-776

Janis JF, Winkelmann RK (1968) Histopathology of the skin in dermatomyositis. A histopathologic study of 55 cases. Arch Dermatol 97(6):640-650

Kuriya N, Kinoshita N, Yokoyama N (1985) Dermatomyositis with rhabdomyosarcoma and panniculitis: report of autopsy case. Nippon Naika Gakkai Zasshi 74:143-148

Lee MW, Lim YS, Choi JH, Sung KJ, Moon KC, Koh JK (1999) Panniculitis showing membranocystic changes in the dermatomyositis. J Dermatol 26(9):608-610

Leung YY, Choi KW, Ho KM, Kun EW (2005) Disseminated cutaneous infection with Mycobacterium chelonae mimicking panniculitis in a patient with dermatomyositis. Hong Kong Med J 11(6):515-519

Lin JH, Chu CY, Lin RY (2006) Panniculitis in adult onset dermatomyositis: report of two cases and review of the literature. Dermatol Sinica 24:194-200

Lorenzo JA, Hernandaz J, Baez O, Castro I, Torrado RM, Rodriguez J (1998) Paniculitis lobulillar como forma de presentacion de una dermatomiositis:presentacion de un caso y revision de la literatura. Actas Dermatosifilogr:400-404

Molnar K, Kemeny L, Korom I, Dobozy A (1998) Panniculitis in dermatomyositis: report of two cases. Br J Dermatol 139(1):161-163

Nakamori A, Yamaguchi Y, Kurimoto I, Kira M, Kosaka H, Itami S, Yoshikawa K (2003) Vesiculobullous dermatomyositis with panniculitis without muscle disease. J Am Acad Dermatol 49(6):1136-1139, doi:10.1016/S0190

Reiter N, El-Shabrawi L, Leinweber B, Berghold A, Aberer E (2011) Calcinosis cutis: part I. Diagnostic pathway. J Am Acad Dermatol 65(1):1-12, quiz 13-14. doi:10.1016/j.jaad.2010.08.038S0190-9622(10)02123-7

Solans R, Cortes J, Selva A, Garcia-Patos V, Jimenez FJ, Pascual C, Bosch J, Vilardell M (2002) Panniculitis: a cutaneous manifestation of dermatomyositis. J Am Acad Dermatol 46(5 Suppl):S148-S150

Weber FP, Gray AMH (1924) Chronic relapsing polydermatomyositis with predominant involvement of the subcutaneous fat. Br J Dermatol 36:544-560

Winkelmann WJ, Billick RC, Srolovitz H (1990) Dermatomyositis presenting as panniculitis. J Am Acad Dermatol 23:127-128

Yamamoto T, Furuhata Y, Tsuboi R (2007) Lipomembranous changes and calcification associated with systemic lupus erythematosus. Clin Exp Dermatol 32(3):278-280, doi:CED2358 10.1111/j.1365-2230.2007.02358.x

\section{Submit your manuscript to a SpringerOpen ${ }^{\odot}$ journal and benefit from:}

- Convenient online submission

- Rigorous peer review

- Immediate publication on acceptance

- Open access: articles freely available online

- High visibility within the field

- Retaining the copyright to your article

Submit your next manuscript at springeropen.com 